\section{An Apple Chlorotic Leaf Spot Virus Isolate from Ornamental Dwarf Flowering Almond (Prunus glandulosa 'Sinensis'): Detection and Characterization}

\author{
Sara Spiegel ${ }^{1}$ \\ Department of Virology, Agricultural Research Organization, The Volcani \\ Center, Bet Dagan 50 250, Israel
}

\author{
Dan Thompson, Aniko Varga, and Delano James \\ Centre for Plant Health, Canadian Food Inspection Agency, 8801 East Saanich \\ Road, Sidney, BC, V8L 1H3, Canada
}

Additional index words. Prunus, ornamental shrub, bioassay, ELISA, RT-PCR

\begin{abstract}
An apple chlorotic leaf spot virus (ACLSV) isolate was detected by TAS-ELISA and RT-PCR in an ornamental dwarf flowering almond (Prunus glandulosa Thunb.). This plant, maintained at the Centre for Plant Health, Sidney, B.C., Canada, has been showing transient leaf symptoms during the spring seasons. A 390-bp fragment and a 1,350-bp product, in the RNA polymerase and the coat protein viral coding regions, respectively, were amplified by RT-PCR from the infected plant. A sequence comparison of the 390bp fragment of this ACLSV isolate (designated as AL1292) with other published isolates, revealed a similarity of $81 \%$ to $84 \%$ at the nucleotide level and $88 \%$ to $100 \%$ at the amino acid level. In contrast to other ACLSV isolates, AL1292 has an exceptionally narrow range of experimental herbaceous and woody hosts, as determined by mechanical and graft inoculation assays. These standard bioassays may not be effective for the detection of the AL1292 isolate because of its limited host range. The results we report in this paper confirm P. glandulosa as a natural host of this virus. Currently it is not known how ACLSV is spread, other than by bud-grafting and possibly by root grafts. The use of virus-tested source plants for the preparation of planting material will minimize its spread.
\end{abstract}

Prunus glandulosa Thunb. is a deciduous, multistemmed shrub, known by the common name dwarf flowering almond (U.S. Department of Agriculture, Agricultural Research Service, The Germplasm Resources Information Network). Native to China and Japan, it has been grown mainly for its flowers coming into full bloom in early spring before new leaves develop. Plants of $P$. glandulosa 'Alba' bear single white flowers while 'Sinensis' (also known as 'Rosea Plena') has double pink flowers. Dwarfflowering almond was introduced to North America as an ornamental flowering bush in 1683 (Adams, 2004). In western Europe, it is known in France since 1785 and later was cultivated in England mainly for cut flowers (Flower Council of Holland, 2002).

Propagation of planting material from seeds is possible but requires stratification before sowing and may take up to 18 months to germinate. Vegetative propagation by rooting cuttings is less time-consuming and, therefore, has been applied routinely for production of planting material. As is the case for other vegetatively propagated plants, transmission of viruses in nursery stock of $P$. glandulosa is a potential problem.

Received for publication 30 Nov. 2004. Accepted for publication 30 Dec. 2004.

${ }^{1}$ For correspondence; e-mail spiegels@volcani. agri.gov.il
Prunus glandulosa, as well as other plants in the genus Prunus, grown for fruits and as ornamentals, are natural hosts of viruses like prunus necrotic ringspot virus (PNRSV), prune dwarf virus (PDV) and plum pox virus (PPV) (Nemeth, 1986). Virus-infected plants often express disease symptoms but may also be symptomless. Apple chlorotic leaf spot virus (ACLSV), the type member of the genus Trichovirus, was reported from the rosaceous species Prunus, Malus, and Pyrus (Martelli et al., 1994) and is also known to occur in oneseed hawthorn (Crataegus monogyna) and medlar(Mespilus germanica) (Nemeth, 1986). ACLSV isolates vary greatly in their biological and molecular properties. Some strains are latent and others may cause symptoms like bark split, dark green sunken mottle of leaves and even graft incompatibility (Nemeth, 1986). Symptoms in Prunus species are generally (Dunez and Delbos, 1988).

Based on bioassays results, Colin and Verhoyen (1975) suggested that leaf symptoms observed in P. glandulosa 'Sinensis' were caused by ACLSV. In this study, we applied biological, serological and molecular methods for the detection and characterization of an ACLSV isolate in the same host. The results we report herein confirm $P$. glandulosa as a natural host of this virus. more severe than in Malus and Pyrus spp.
Virus isolates and symptoms. A dwarf flowering almond (P. glandulosa 'Sinensis') plant(Fig. 1a) with foliar symptoms suggesting a virus infection, was obtained initially from Prosser, Wash., and maintained (accession number Q1292-01) at the Centre for Plant Health, Sidney, B.C., Canada. This plant served as the source material for this study. Chlorotic line pattern and vein breaking symptoms (Fig. 1b) have been observed on expanded leaves of this plant during consecutive spring seasons with a gradual reduction in intensity during summer.

Mechanical and graft transmission. Initial mechanical transmission of virus was done with symptomatic leaves of plant Q1292-01 ground in $0.01 \mathrm{M}$ Tris, $\mathrm{pH} 8.5 ; 0.01 \mathrm{M} \mathrm{MgSO}_{4}$; $1.0 \%$ nicotine. The macerate was inoculated onto expended leaves of Chenopodium quinoa plants. For determination of an experimental host range, two successive mechanical passages in $C$. quinoa, using single local lesions ground in the above buffer (without nicotine), were done before inoculation of the following herbaceous plants: Beta vulgaris L., C. amaranticolor Coste and Reyn., C. murale L., C. quinoa Willd., Cucumis sativus L., Datura stramonium L., Gomphrena globosa L., Lactuca sativa L., Nicotiana benthamiana Domin., N. clevelandii Gray., N. glutinosa L., N. occidentalis Wheeler, N. rustica L., N. tabacum L. 'Harrownova', N. tabacum L. 'Samsun', N. tabacum L. 'Xanthi', Petunia hybrida 'Coral Satin', Phaseolus vulgaris L.'Black Turtle', Vigna unguiculata L., and Zinnia elegans L. Plants were grown in the greenhouse $\left(22\right.$ to $\left.24^{\circ} \mathrm{C}\right)$ for up to 4 weeks and observed for symptom development.

Graft inoculation on woody indicators was done both in the greenhouse and the field (Jelkmann, 2001). Two buds from the Q1292-01 plant were T-budded onto each indicator plant. Greenhouse indicator buds and the test buds were grafted simultaneously to the rootstock. Potted rootstocks were budded in the summer (August), moved to cold incubation $\left(4{ }^{\circ} \mathrm{C}\right)$ in the fall (October) and in January brought into a glasshouse (22 or 18 ${ }^{\circ} \mathrm{C}$ ) for symptom expression. Field indicator buds were applied to the rootstock in the summer preceding inoculation with the Q1292-01 buds. The following indicators, recommended by the International Working Group on Fruit Tree viruses (Jelkmann, 2001), and additional ones (in brackets), were used: a) greenhouse: $P$. persica L. GF305 (and 'Siberian C') seedlings, P. tomentosa Thunb., Pyronia veitchii Trab., Malus platycarpa Rehd., M. pumila Mill. 'Spy 227' and 'R12740-7A'; b) field: P. avium L. 'Bing' and 'Sam'; P. serrulata L. 'Kwanzan' and 'Shirofugen'; P. persica L. 'Elberta' (and 'Halford'); and P. armeniaca L. 'Tilton'. ACLSV isolates, maintained in Malus, Pyrus, Prunus and Medlar, and healthy plants, were included as positive and negative controls, respectively.

Enzyme-linked immunosorbent assay (ELISA). Triple-antibody sandwich (TAS)- 


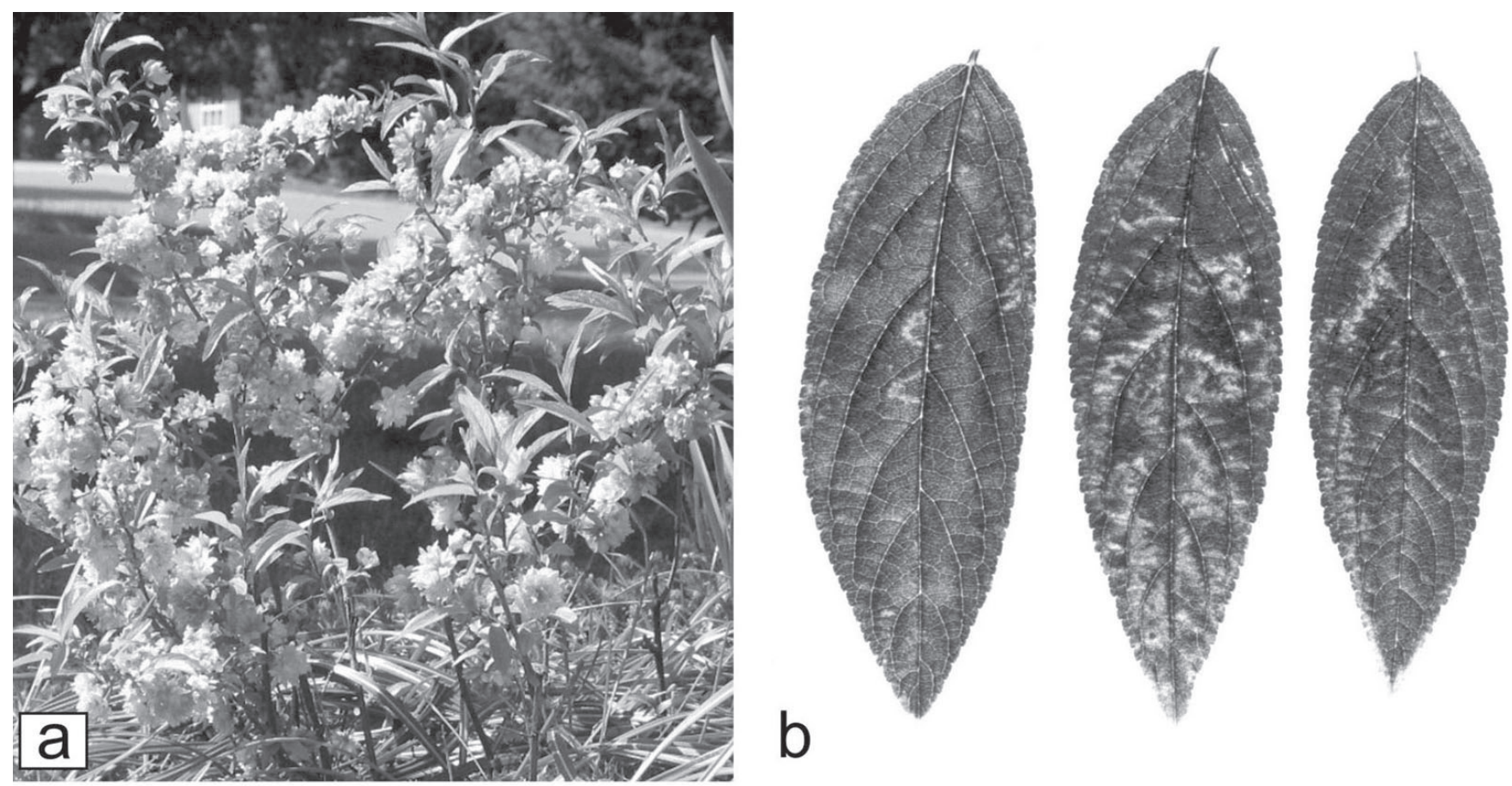

Fig. 1. Dwarf flowering almond (Prunus glandulosa 'Sinensis') Q1292-01 multi-stemmed shrub in bloom (a). Chlorotic line pattern and vein breaking symptoms on three fully expanded leaves of Q1292-01 (b).

ELISA, using the ACLSV polyclonal antibody (PAb) no. 151012 (Bioreba, Reinach, Switzerland) and the monoclonal antibody (MAb) 113P B2 (Thompson, 1990), was done as described previously (Spiegel et al., 1998) except that plant samples were ground in $0.01 \mathrm{M}$ Tris, $\mathrm{pH}$ $8.5 ; 0.01 \mathrm{M} \mathrm{MgSO}_{4} .7 \mathrm{H}_{2} \mathrm{O} ; 2 \%$ polyvinylpyrrolidone, $0.2 \%$ skim milk powder; $1 \%$ nicotine; $0.05 \%$ Tween-20. Plates coated with the PAb (diluted $1: 1000$ ) in $0.05 \mathrm{M}$ sodium carbonate, pH 9.6 were stored overnight at $4{ }^{\circ} \mathrm{C}$. The MAb and the conjugate were used at a dilution of $1: 1000$ and incubated at $4{ }^{\circ} \mathrm{C}$ for $16 \mathrm{~h}$ and $37^{\circ} \mathrm{C}$ for $3 \mathrm{~h}$, respectively. Samples with absorbance values (at $405 \mathrm{~nm}$ ) greater than three times the healthy control were considered positive. The possibility of infection with PNRSV, PDV and PPV, common in Prunus spp., was tested by ELISA with virus-specific antibodies.

Reverse transcription-polymerase chain reaction (RT-PCR). Two coding regions in the ACLSV genome were targeted-the RNA polymerase located in open reading frame (ORF) 1 and the coat protein (CP) in ORF3 (German-Retana et al., 1997). The oligonucleotide primers used in this study were designed on the basis of comparison of published and partial sequencing of ACLSV isolates. Amplification of a $390 \mathrm{bp}$ product from the RNA polymerase coding region, was obtained using the forward primer $4 \mathrm{~F}$ (5'-TTGCCATTATGAGGTTCACTGG-3'), nucleotides (nt) 5206-5227 and the reverse primer 4R (5'-GATGTGAATAGAGCC TCTCACC-3'), complementary to nt 5576-5597, in ACLSV p863 strain (M58152) (German et al., 1990). The sequence information for primers $4 \mathrm{~F}$ and $4 \mathrm{R}$ was obtained from $\mathrm{J}$. Kummert (Gembloux, Belgium) (personal communication). The forward primer $\mathrm{CPF} 2$ (5'-AGCAGGCCATGCTGCAGAAGTTTC-
3'), nt 6079-6102 and the reverse primer CPR1 (5'-ACACTTGAGCACACA ACACAC-3'), complementary to nt 7408-7428, were used for amplification of the 1,350-bp product in the $\mathrm{CP}$ coding region.

Total RNA was extracted from plant tissue (Spiegel et al., 1996) and suspended in $30 \mu \mathrm{L}$ of diethyl pyrocarbonate (depc)-treated $\mathrm{H}_{2} \mathrm{O}$. The RT and PCR reactions were done as described previously (James, 1999) except that for the 1,350-bp fragment, the annealing step was done at $58^{\circ} \mathrm{C}$ for $45 \mathrm{~s}$. The volume of the PCR reactions was $25 \mu \mathrm{L}$. Reaction product $(10$ $\mu \mathrm{L}$ ) was analyzed by gel electrophoresis in $1 \%$ agarose with ethidium bromide staining.

Cloning of cDNA, sequencing and sequence analysis. The amplified 390-bp fragment, was identified by agarose gel electrophoresis (described above), excised and purified using the MiniElute Gel Extraction kit(Qiagen, Valencia, CA). Gel-purified PCR products were ligated into the pCR 2.1 TOPO Vector and cloned using the TOPO TA Cloning kit (Invitrogen, Carlsbad, Calif.). Sequencing was done as described by James et al. (2001). Nucleotide sequence data were compiled and analyzed using the Clone Manager 6 (version 6.00, Scientific and Education Software, Durham, N.C.) and Clustal-X (version 1.81) (Thompson etal., 1997). Database searches were performed with BLAST (blastn) programs at the National Centre for Biotechnology Information (NCBI, National Institutes of Health).

\section{Results}

Host range. Transmission of the virus from dwarf flowering almond Q1292-01 to C. quinoa was achieved using either leaves, flowers or roots. Symptoms were observed only in inoculated C. amaranticolor, C. mu- rale and $C$. quinoa out of 20 herbaceous host plants, belonging to 6 different families. Local lesions developed on inoculated leaves of all three hosts about 10 to $14 \mathrm{~d}$ after inoculation and systemic lesions, distortion, line pattern and mottling were observed on upper leaves following $\geq 14 \mathrm{~d}$.

Graft inoculation of buds from the dwarf flowering almond plant onto a range of diagnostically susceptible woody indicators listed above, did not induce any visible symptoms, neither in the greenhouse nor in the field. Under the same conditions, $P$. persica GF305 and 'Siberian C' seedlings, grafted with buds from five known ACLSV infected stone fruit; and $P$. veitchii, M. platycarpa and M. sylves-

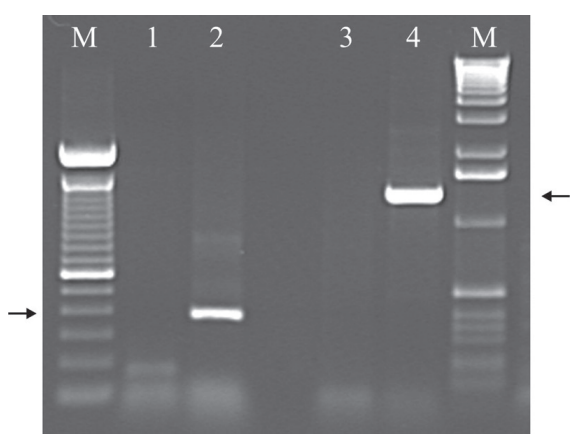

Fig. 2. Reverse transcription polymerase chain reaction (RT-PCR) using apple chlorotic leaf spot virus-specific primers $4 \mathrm{~F}$ and $4 \mathrm{R}$ to amplify a 390-bp fragment in the RNA polymerase coding region and primers CPF2 and CPR1 to amplify a 1,350-bp fragment in the coat protein coding region. Lane $\mathrm{M}$ (left ) = 100-bp DNA ladder; (right) $=1-\mathrm{Kb}$ DNA ladder; lane $1=$ healthy GF305; lane 2 $=390$ bp fragment; lane $3=$ healthy almond; lane $4=1,350$-bp fragment. The arrows on the left and right indicate the position of the 390- and 1,350-bp fragments, respectively. 

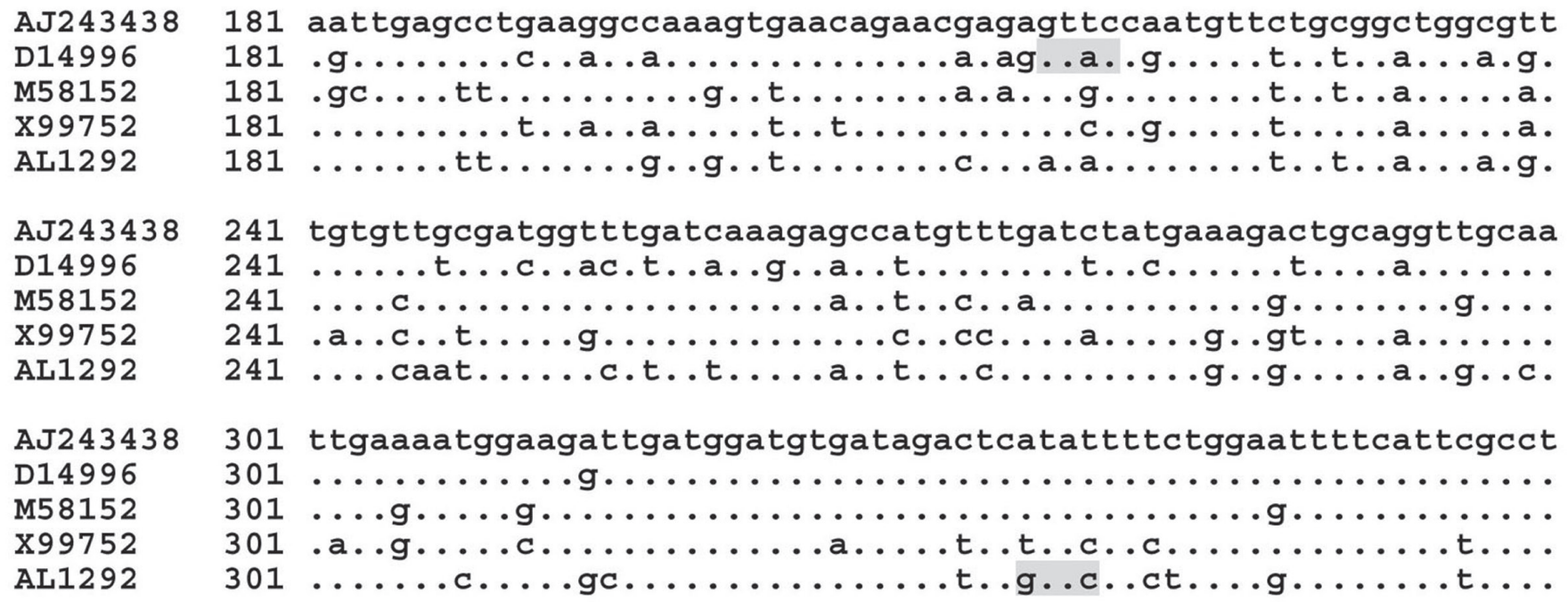

Fig. 3. Multiple alignment of the nucleotide sequence of the fragment (nt 181-360) amplified by RT-PCR in the replicase region of apple chlorotic leaf spot virus (ACLSV). Virus isolates include AL1292 derived from flowering almond Q1292-01; previously described ACLSV isolates are indicated by their GenBank accession numbers AJ243438, D14996, M58152, and X99752. Dots indicate identical nucleotides, bold letters show modifications and gtac restriction sites are boxed in gray.

tris 'Spy 227' and 'R12740-7A' grafted with buds from six known ACLSV infected pome fruits, used as positive controls, developed symptoms typical to this virus (Brunt et al., 1996; Nemeth, 1986).

ELISA. Samples from the Q1292-01 plant and inoculated, symptomatic, C. amaranticolor, C. murale and C. quinoa, tested positive for ACLSV in TAS-ELISA. No reaction was obtained using extracts from the other inoculated herbaceous plants listed above. All the plant samples included in this study tested negative for PNRSV, PDV, and PPV in ELISA assays and, therefore, the possibility of multiple infections is unlikely.

Reverse transcription-PCR and sequence analysis. A 390-bp fragment was amplified, using primers $4 \mathrm{~F} / 4 \mathrm{R}$ (Fig. 2, lane 2) and a 1,350-bp product was obtained with primers CPF1/CPR2 (Fig. 2, lane 4), from leaf samples of plant Q1292-01. These products are from the RNA polymerase and CP coding regions of ACLSV, respectively. No amplification was observed for the healthy controls (Fig. 2, lanes 1 and 3).

Two cDNA clones, containing the 390-bp fragment, generated using total RNA extracted from Q1292-01, were sequenced. The identity between the two clones derived from samples amplified separately was 100\% (not shown) and, therefore, this ACLSV isolate was designated as AL1292. An alignment and sequence comparison of the 390-bp fragment of AL1292 with ACLSV isolates from plum (AJ243438 and M58152), apple (D14996) and cherry (X99752) revealed $15 \mathrm{nt}$ modifications unique to isolate AL1292 and resulting in a $81 \%$ to $84 \%$ similarity between the latter and the other isolates. Two close nucleotide alterations, a to $\mathrm{g}$ (nt 335) and t to c (nt 338) resulted in the sequence - gtac (Fig. 3, boxed in gray), a cleavage site recognized by the enzyme RsaI, unique to isolate AL1292. A comparative analysis of deduced amino acid sequences with the isolates listed above showed only three modifications, resulting in a $98 \%$ to $100 \%$ similarity and reflecting on the 12 nucleotide modifications which did not result in amino acid changes (not shown).

\section{Discussion}

ACLSV was reported from many species within the Rosaceae with an emphasis on pome- and stone fruit species (Nemeth, 1986). Based on results of bioassays, carried out about 30 years ago, Colin and Verhoyen (1975) suggested that ACLSV was the causal agent inducing leaf symptoms in the ornamental dwarfflowering almond (P. glandulosa 'Sinensis'). This paper presents biological, serological and molecular evidence of an ACLSV isolate (AL1292) detected in the same host.

ACLSV was detected in a dwarf flowering almond (Q1292) by TAS-ELISA and by RT-PCR, amplifying two ACLSV-specific products (390 and 1,350 bp) in the RNA polymerase and the $\mathrm{CP}$ region, respectively. A high degree of similarity was shown between the nucleotide sequence and deduced amino acids of the 390-bp cDNA fragment from the RNA polymerase region of ACLSV AL1292 and isolates AJ243438 and M58152, D14996, and X99752 originating from fruit tree hosts (two plums, one apple and one cherry, respectively). Interestingly, a RsaI cleavage site (gtac, nt 335-338), resulting from 2 nt modifications at this particular location, is unique to isolate AL1292. A similar site can be found in the same genomic region of isolate D14996, but at a different location (nt 216-219) (Sato et al., 1993). Location of restriction sites within PCR products of virus isolates might be useful for typing purposes (Spiegel et al., 1999).

ACLSV has a wide range of symptoms in a number of natural and experimental hosts (Nemeth, 1986). In contrast, ACLSV isolate AL1292 has an exceptionally narrow range of experimental hosts. It infected three of 20 herbaceous test plant species and did not cause symptoms in any of 14 standard Prunus and Malus woody indicator plant hosts, customarily used to detect ACLSV isolates by graft inoculation. Under the same conditions, 11 known ACLSV-infected stone and pome fruit hosts developed typical symptoms on woody indicators. Although in general indexing on woody indicators is still considered most reliable (Jelkmann, 2001), with isolate AL1292, the standard bioassays, both in the field and the greenhouse, may not be effective because of its limited host range.

The one plant of P. glandulosa 'Sinensis' that we studied only showed transient leaf symptoms. It would seem interesting to examine other sources of $P$. glandulosa for the presence of ACLSV and to compare any with AL1292. Judging from our specimen, the economic impact of ACLSV in P. glandulosa is limited, resembling that of other known ACLSV isolates. AL1292 is unlikely to be spread by vectors or in seed, but rather by bud grafting and possibly by root grafts (Brunt et al., 1996). The potential of a virus-infected, often symptomless, ornamental tree or shrub to become a reservoir of viruses from which pathogens might be spread should be of concern. Recently, PPV, the most devastating virus in Prunus spp was identified in a dwarfflowering almond ( $P$. glandulosa) plant growing at a homeowner's property within the quarantine zone in York County, Pa. (Richwine, 2003).

Since dwarfflowering almond is generally propagated by self-rooted cuttings, ACLSV, if present, might be transmitted from one generation to the next, resulting in a horizontal spread of this virus. Using virus-tested plants as a source of planting material or growing new dwarf flowering plants from seeds should minimize the spread of ACLSV and other virus diseases in this ornamental plant.

\section{Literature cited}

Adams, D.W. 2004. Restoring American gardens: An Encylopedia of heirloom ornamental plants, 1640-1940. Timber Press, Portland, Ore

Brunt, A.A., K. Crabtree, M.J. Dallwitz, A.J. Gibbs, L. Watson, and E.J. Zurcher (eds.) 1996. Plant viruses online: Descriptions and lists from the VIDE database. 20 Aug. 1996.

Colin, J. and M. Verhoyen. 1975. Identification des 
virus chez les Prunus ornementaux en Belgique. Rev. de 1'Agr. 4:935-951.

Dunez, J. and R. Delbos. 1988. Closteroviruses, p. 5-7. In: I.M. Smith, J. Dunez, R.A. Lelliot, D.A. Phillips, and S.A. Archer (eds.). European handbook of plant diseases. Blackwell, Oxford.

Flower Council of Holland. 2002. http://www. flowercouncil.org.

German, S., T. Candresse, M. Lanneau, J.C. Huet, J.C. Pernollet, and J. Dunez. 1990. Nucleotide sequence and genomic organization of apple chlorotic leaf spot virus. Virology 179:104-112.

German-Retana, S., B. Bergey, R. Delbos, T. Candresse, and J. Dunez. 1997. Complete nucleotide sequence of the genome of a severe cherry isolate of apple chlorotic leaf spot trichovirus (ACLSV). Arch. Virol. 142:833-841.

James, D. 1999. A simple and reliable protocol for the detection of apple stem grooving virus by RT-PCR and in multiplex PCR. J. Virol. Meth.
$83: 1-9$.

James, D., W.E. Howell, and G. Mink. 2001. Molecular evidence of the relationship between a virus associated with flat apple disease and cherry rasp leaf virus as determined by RT-PCR. Plant Dis. 85:47-52.

Jelkmann, W. 2001. Detection of virus and virus-like diseases of fruit trees - Laboratory assays, Bioassays and Indicators. Acta Hort. 550:473-492.

Martelli, G.P., T. Candresse, and S. Namba. 1994. Trichovirus, a new genus of plant viruses. Arch. Virol. 134:451-455.

Nemeth, M. 1986. Virus, mycoplasma and rickettsia diseases of fruit trees. Martinus Nijhoff Publ., The Netherlands.

Richwine, N.S.H. 2003. Plum pox update-PDA 23 June 2003. http://www.ceris.purdue.edu/napis/pests/ppox.

Sato, K., N. Yoshikawa, and T. Takahashi. 1993. Complete nucleotide sequence of the genome of an apple isolate of apple chlorotic leaf spot virus. J. Gen. Virol. 74:1927-1931.

Spiegel, S., A. Rosner, Y. Tam, S. Zilkah, and L. Krizbai. 1998. Detection of prune dwarf virus in sweet cherry in Israel. Acta Hort. 472:249-255.

Spiegel, S., S. Scott, V. Bowman-Vance, Y. Tam, N.N. Galiakparov, and A. Rosner. 1996. Improved detection of prunus necrotic ringspot virus by the polymerase chain reaction. Euro. J. Plant Pathol. 102:681-685.

Thompson, D.A. 1990. Purification and serology of apple chlorotic leaf spot virus isolated from Prunus glandulosa. MS thesis. Univ. B.C., Vancouver, Canada.

Thompson, J.D., T.J. Gibson, F. Plewniak, F. Jeanmougin, and D.G. Higginsm. 1997. The CLUSTAL X windows interface: flexible strategies for multiple sequence alignment aided by quality analysis tools. Nucleic Acids Res. 24:4876-4882. 